configuration interactions is necessary to obtain a solution where the energies of the different geometries of the singlet excited state are stable. As the $\mathrm{CI}$ number was increased the energies of the perpendicular geometries were less affected (lowered) compared with the $E$ and $Z$ ones.

The results are summarized in Figure 4. As regards the Franck-Condon transition energies the agreement with experimental data is fair. The structureless absorption and emission spectra of 1 and $\mathbf{2}$ make the energy evaluations somewhat ambiguous. The longest wavelength absorption maxima at $153 \mathrm{~K}$ (where the vibronic structures in the spectra of 3 are resolved) correspond to the energies 86,83 , and $75 \mathrm{kcal} \mathrm{mol}^{-1}$ for 1,2 , and 3 , respectively. The Franck-Condon energies similarly estimated from the emission spectra are 64,66 , and $72 \mathrm{kcal} \mathrm{mol}^{-1}$.

A prerequisite for an adiabatic mechanism is that there are no energy minima on the excited-state energy surface in the regions of $90^{\circ}$ double bond twists. The calculated energy difference between ${ }^{1} Z p^{*}$ and ${ }^{1} Z Z^{*}\left(5.1 \mathrm{kcal} \mathrm{mol}^{-1}\right)$ and that between ${ }^{1} Z E^{*}$ and ${ }^{1} E p^{*}\left(6.0 \mathrm{kcal} \mathrm{mol}^{-1}\right)$ are remarkably close to the experi- mentally determined energy barriers for the adiabatic isomerizations of 1 and $2\left(4.6 \mathrm{kcal} \mathrm{mol}^{-1}\right.$ for both).

For comparison the method of calculation applied to stilbene gives a distinct global minimum for a twisted structure starting from either cis- or trans-stilbene.

Outlook. The simple extension of the conjugated $\pi$-system of stilbene to a $p$-styrylstilbene changes the mechanism for the photoinduced $Z / E$ isomerization from diabatic to mainly adiabatic processes. This together with previous findings by us and others of adiabatic singlet and triplet $Z / E$ photoisomerizations encourage us to try to explore the scope and limitations as well as applications of this conceptually new photoreaction in molecules with extended linear or cyclic $\pi$-systems.

Acknowledgment. Financial support from the Swedish Natural Science Research Council and the Swedish Board of Technical Development is gratefully acknowledged. We also thank Prof. K. Müllen, Mainz, for discussions and a sample of 3,5-di-tertbutylbenzyltriphenylphosphonium bromide.

\title{
Phthalocyaninato Polysiloxanes Substituted with Crown Ether Moieties
}

\author{
O. E. Sielcken, ${ }^{\ddagger}$ L. A. van de Kuil, ${ }^{\ddagger}$ W. Drenth, ${ }^{\ddagger}$ J. Schoonman, ${ }^{\S}$ and R. J. M. Nolte ${ }^{*, \mid}$
}

Contribution from the Department of Organic Chemistry, University of Utrecht, Padualaan 8 , $3584 \mathrm{CH}$ Utrecht, The Netherlands, the Laboratory for Inorganic Chemistry, Delft University of Technology, Julianalaan 136, 2628 BL Delft, The Netherlands, and the Department of Organic Chemistry, University of Nijmegen, Toernooiveld, 6525 ED Nijmegen, The Netherlands. Received June 13, 1989

\begin{abstract}
We describe the synthesis and characterization of phthalocyaninato polysiloxanes substituted with $15-\mathrm{crown}-5$, 18-crown-6, and 21-crown-7 rings. The degree of polymerization of the polymer samples depends on the size of the crown ether rings and varies between 6 and 18 units. NMR spectroscopy reveals that the polysiloxanes have a rigid structure with staggered phthalocyaninato $(\mathrm{Pc})$ units. The binding of alkali-metal ions to the plymers and their monomers is reported and discussed. Upon polymerization of the phthalocyaninato dihydroxysilanes the electronic conductivity increases from $<10^{-9}$ to $10^{-7} \mathrm{~S} / \mathrm{m}$. The polymer substituted with 21 -crown-7 rings conducts sodium ions.
\end{abstract}

Phthalocyanines (Pc's) substituted with crown ether rings are currently receiving great interest. ${ }^{1,6}$ Recently, we reported that these molecules can be aggregated by addition of alkali-metal salts, which become complexed to the crown ether rings. ${ }^{1 b, c}$ Electrical measurements of the aggregated species revealed an increase in electrical conductivity that is $2-3$ powers of 10 higher than that of the nonaggregated ones.

In this paper we report another method of aggregating phthalocyanines. $^{2}$ This method, first described by Joyner and Kenney, ${ }^{3 a}$ involves the polycondensation of a phthalocyaninato dihydroxysilane containing four crown ether rings. In this way a stacked quasi-one-dimensional arrangement of crowned Pc's is achieved in which the central silicon atoms are bridged through $\mathrm{O}^{2-}$ ligands (Figure 1). These stacks are expected to transport electrons and ions in the stacking direction: electrons via the central Pc macrocycles and cations via the crown ether moieties. Such compounds when incorporated in vesicle bilayers could be used as synthetic models to mimic both electron and ion channels of natural transport systems.

Substituted and unsubstituted phthalocyaninato polysiloxanes, $[\mathrm{PcSiO}]_{m}$, have been studied by many scientists. ${ }^{3}$ Unsubstituted

\footnotetext{
${ }^{\dagger}$ University of Utrecht.

Delft University of Technology.

"University of Nijmegen.
}

Table I. ${ }^{13} \mathrm{C}$ Chemical Shifts of $\mathbf{5 c}$ in Solution and in the Solid State ${ }^{a}$

\begin{tabular}{lllllc}
\hline & $\mathrm{C}_{1}, \mathrm{C}_{1^{\prime}}$ & $\mathrm{C}_{4}, \mathrm{C}_{4^{\prime}}$ & $\mathrm{C}_{2}, \mathrm{C}_{2^{\prime}}$ & $\mathrm{C}_{3}, \mathrm{C}_{3^{\prime}}$ & crown ether \\
\hline solution $^{b}$ & 151.3 & 155.0 & 132.3 & 108.1 & 72.4 \\
solid state & 151.8 & 151 & 129.5 & 102.5 & 70.9 \\
\hline
\end{tabular}

${ }^{a}$ In ppm relative to tetramethylsilane. ${ }^{b}$ Solvent $\mathrm{CD}_{3} \mathrm{OD}$.

polysiloxanes are formed by the uncatalyzed polycondensation of phthalocyaninato dihydroxysilane for $1-12 \mathrm{~h}$ at $440^{\circ} \mathrm{C}$ under

(1) (a) Hendriks, R.; Sielcken,O. E.; Drenth, W.; Nolte, R. J. M. J. Chem. Soc., Chem. Commun. 1986, 1464-1465. (b) Sielcken, O. E.; Schram, J.; Nolte, R. J. M.; Schoonman, J.; Drenth, W. J. Chem. Soc., Chem. Commun. 1988, 108-109. (c) Sielcken, O. E.; van Lindert, H. C. A.; Schram, J.; Schoonman, J.; Drenth, W;; Nolte, R. J. M. Ber. Bunsenges. Phys. Chem. 1989, 93, 702-707. (d) Kobayashi, N.; Nishiyama, Y. J. Chem. Soc., Chem. Commun. 1986, 1462-1463. (e) Ahsen, V.; Yilmazer, E.; Ertas, M.; Bekâroglu, Ö. J. Chem. Soc., Dalton Trans. 1988, 401-406. (f) Ahsen, V.; Yilmazer, E.; Bekâroglu, Ö. Makromol. Chem. 1988, 189, 2533-2543. (g) Sarigul, S.; Bekâroglu, Ō. Chem. Ber. 1989, 122, 291-292.

(2) A preliminary communication has appeared: Sielcken, O. E.; van der Kuil, L. A.; Drenth, W.; Nolte, R. J. M. J. Chem. Soc., Chem. Commun. 1988, 1232-1233. Independently, the synthesis of phthalocyaninato polysiloxanes substituted with 15-crown-5 rings was reported by Ahsen, V.; Yilmazer, E.; Gürek, A.; Gül, A.; Bekâroglu, Ö. Helv. Chim. Acta 1988, 7 I, 1616-1621. 
Scheme I<smiles>N#Cc1cc2c(cc1C#N)OCCOCCOCCOCCOCCO2</smiles>

2

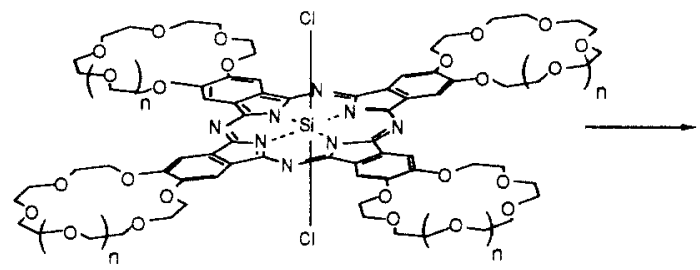

4<smiles>[3H]C1COCCOCCOCCOC2=CC3=CC=C(C(=N)NC2=N)C(CO3)CO1</smiles>

3

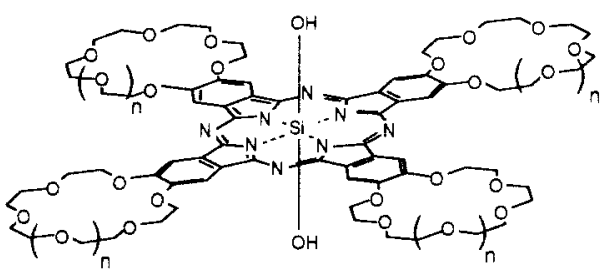

5

$a: n=0$
$b: n=1$
$c: n=2$

vacuum, or in 1-chloronaphthalene at reflux. ${ }^{3 a}$ These polymers, for which a degree of polymerization, $m$, of 70-140 can be reached, exhibit high thermal and chemical stabilities. Structural information, obtained by $\mathrm{X}$-ray powder diffraction, has shown these polymers to have an orthorhombic structure with an interplanar Pc distance of $3.33 \AA$ and a staggered arrangement of the Pc macrocycles (staggering angle $=39^{\circ}$ ). Polycrystalline samples are reported to exhibit a room temperature conductivity of $10^{-4}-10^{-5} \mathrm{~S} / \mathrm{m}^{3 \mathrm{~b}}$

Peripherally substituted polysiloxanes cannot be synthesized under the above-mentioned conditions because of thermal degradation of the substituents. Wegner and co-workers ${ }^{3 \mathrm{j}}$ have developed a milder procedure for the polycondensation of substituted Pc's by using metal salt catalysts, though little is known about the operative reaction mechanism. ${ }^{3 n}$ The rate of reaction is very low, and relatively low molecular weight polymers are obtained; chain lengths of tetra-tert-butyl-substituted ${ }^{\text {hh }}$ and octakis(dodecoxymethyl)-substituted ${ }^{31}$ phthalocyaninato polysiloxanes were estimated to be between 10 and 25 Pc units. ${ }^{3 i, j}$ These polymers are soluble in common organic solvents. Very recently, Wegner and co-workers ${ }^{3 \mathrm{n}}$ developed a route to higher molecular weight polymers. This route involves the polycondensation of octakis(dodecoxy)-substituted phthalocyaninato silanols in which the hydroxyl functions have first been converted with trifluoroacetic acid anhydride into good leaving groups. They proved the polymers to have a rigid rodlike structure with an interplanar $\mathrm{Pc}$

(3) (a) Joyner, R. D.; Kenney, M. E. Inorg. Chem. 1962, 1, 717-718. Kroenke, W. J.; Sutton, L. E.; Joyner, R. D.; Kenney, M. E. Ibid. 1963, 2 1064-1065. (b) Peterson, J. L.; Schramm, C. S.; Stojakovic, D. R.; Hoffman, B. M.; Marks, T. J.; J. Am. Chem. Soc. 1977, 99, 286-288. (c) Wheeler, B. L.; Nagasubramanian, G.; Bard, A. J.; Schechtman, L. A.; Dininny, D. R. Kenney, M. E. J. Am. Chem. Soc. 1984, 106, 7404-7410. (d) Orthmann, E A.; Enkelmann, V.; Wegner, G. Makromol. Chem., Rapid Commun. 1983, 4, 687-692. (e) Dirk, C. W.; Inabe, T.; Schoch, K. F.; Marks, T. J. J. Am. Chem. Soc. 1983, 105, 1539-1510. (f) Diel, B. N.; Inabe, T.: Lyding, J. W.; Schoch, K. F.; Marks, T. J. Ibid. 1983, 105, 1551-1567. (g) Ciliberto, E. Doris, K. A.; Pietro, W. J.; Reisner, G. M.; Ellis, D. E.; Fragala, I.; Herbstein F. H.; Ratner, M. A.; Marks, T. J. Ibid. 1984, 106, 7748-7761. (h) Metz, J.; Pawlowski, G.; Hanack, M.; Z. Naturforsch., B: Anorg. Chem., Org. Chem 1983, 38, 378-382 (i) Hanack, M. Metz, J. Pawlowski, G. Chem. Ber. 1982, 115, 2836-2853. (j) Orthmann, E.; Wegner, G. Makromol. Chem Rapid. Commun. 1986, 7, 243-247. (k) Hale, P. D.; Pietro, W. J.; Ratner, M. A.; Ellis, D. E.; Marks, T. J. J. Am. Chem. Soc. 1987, 109, 5943-5947. (1) Sirlin, C.; Bosio, L.; Simon, J. J. Chem. Soc., Chem. Commun. 1988 236-237. (m) Meyer, G. Wöhrle, D. Makromol. Chem 1974, 175, 714-728. (n) Caseri, W.; Sauer, T.; Wegner, G. Makromol. Chem., Rapid Commun. 1988, 9, 651-657.

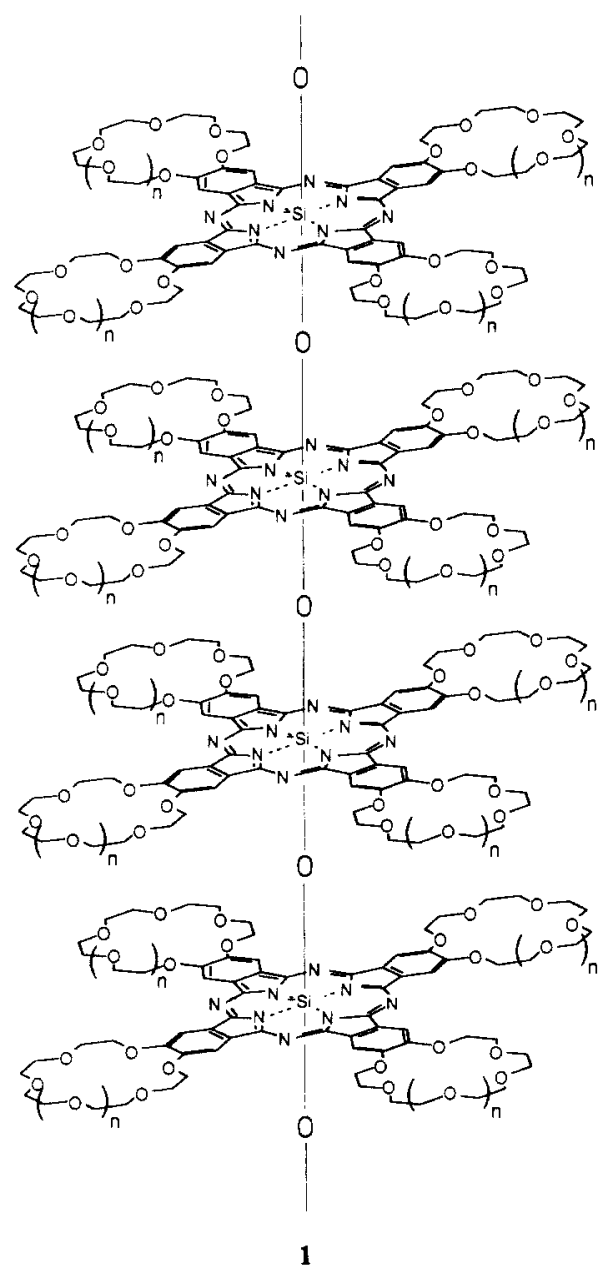

Figure 1. Linear chain of "crowned" phthalocyanines.

spacing of $3.4 \AA$ and a Si-O-Si bond angle of $180^{\circ}$.

This paper deals with the synthesis of phthalocyaninato silanols containing 15-crown-5, 18-crown-6, and 21-crown-7 rings and of their polycondensation products prepared by a metal salt catalyzed polycondensation. Spectroscopic characterization, alkali-metal binding data, and electrical properties of the prepared compounds are reported. 

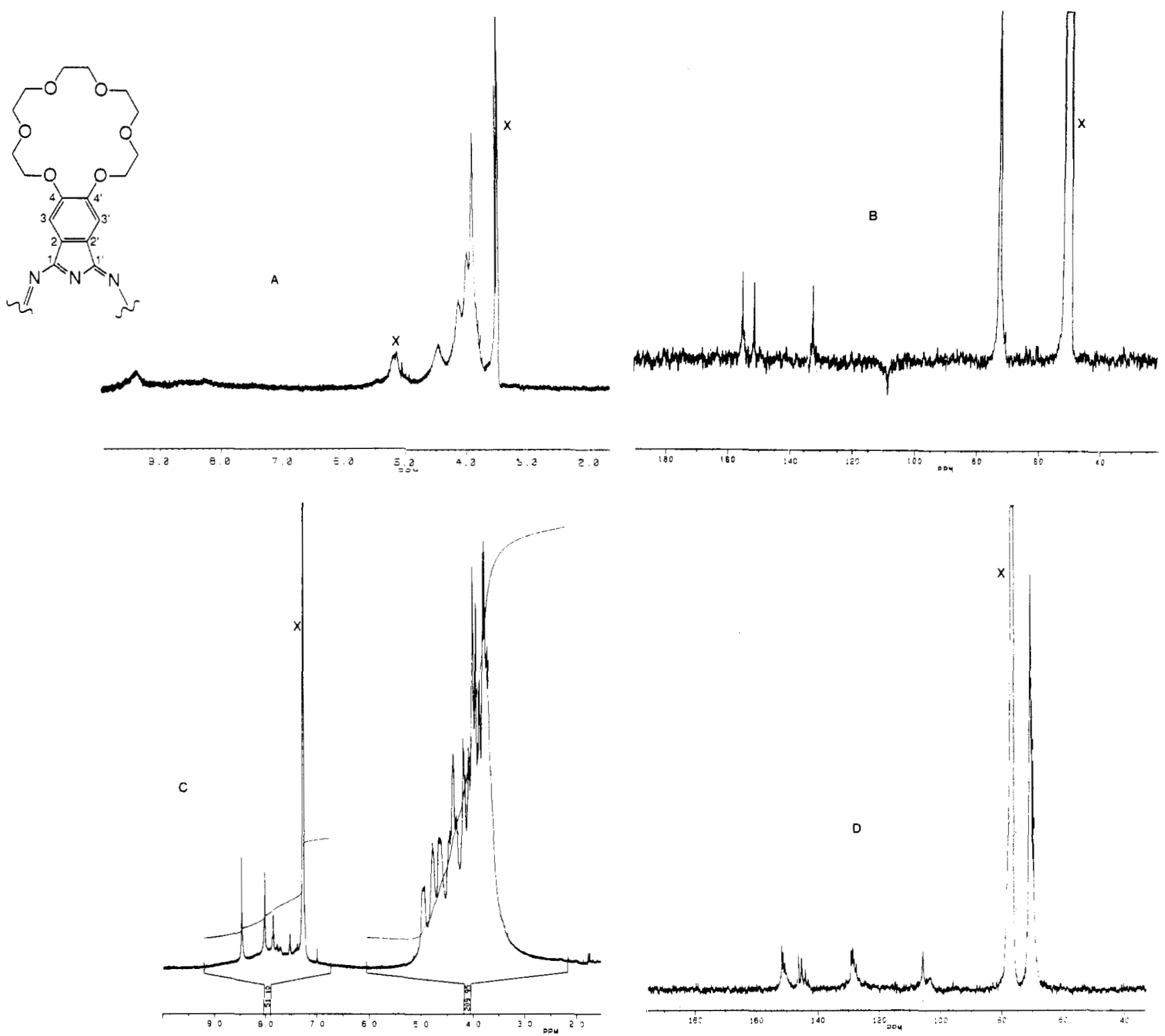

Figure 2. NMR spectra of $5 \mathrm{c}$ and of its oligomer $(m=3-4)$ in solution: (A) $200 \mathrm{MHz}^{1} \mathrm{H}$ NMR (CD,OD) spectrum of $5 \mathrm{c}$, (B) $200 \mathrm{MHz}{ }^{13} \mathrm{C} \mathrm{NMR}$ $\left(\mathrm{CD}_{3} \mathrm{OD}\right)$ spectrum of $5 \mathrm{c},(\mathrm{C}) 400 \mathrm{MHz}{ }^{1} \mathrm{H}$ NMR $\left(\mathrm{CDCl}_{3}\right)$ spectrum of oligomeric $5 \mathrm{c}$, (D) $400 \mathrm{MHz}^{13} \mathrm{C} \mathrm{NMR}\left(\mathrm{CDCl}_{3}\right)$ spectrum of oligomeric $5 \mathrm{c}$. Signals marked $\mathrm{X}$ are due to solvent.

\section{Results and Discussion}

Synthesis. 4,5-Dicyanobenzo-crown ether (2a-c, Scheme I, Figure 1) was converted into the corresponding 1,3-diimino-1,3dihydroisoindole derivative $(3 a-c)$ by reaction with sodium methoxide and ammonia in methanol ${ }^{4}$ (yield $83 \%$ ). Sodium salts, complexed in the crown ethers of $3 \mathrm{a}-\mathrm{c}$, were removed by treatment with an ion exchange resin. Reaction of $3 \mathrm{a}-\mathrm{c}$ with $\mathrm{SiCl}_{4}$ in quinoline ${ }^{3 e}$ at elevated temperatures $\left(130^{\circ} \mathrm{C}\right)$ produced the phthalocyaninato dichlorosilanes $4 a-c$. These dichloro compounds are extremely air- and moisture-sensitive. Hydrolysis is rapid if the solvent is not rigorously anhydrous or when a sample is kept open to the air. Compounds $4 a-c$ were readily hydrolyzed by water to give the dihydroxysilane compounds $5 \mathbf{a}-\mathbf{c}$ ( $30 \%$ yield from the isoindole derivative). Polycondensation of $\mathbf{5 a - c}$ was induced by heating in quinoline at $200^{\circ} \mathrm{C}$ in the presence of $\mathrm{CaCl}_{2}$ as catalyst. ${ }^{3 \mathrm{j}}$ Reaction times of $2-5 \mathrm{~h}$ gave a mixture of dimeric and trimeric compounds which are soluble in organic solvents. Prolonged heating $(\sim 70 \mathrm{~h})$ resulted in the formation of higher weight polymers (yield $70 \%$ ) which are insoluble in common organic

(4) Pawlowski, G.; Hanack, M. Synthesis, 1980, 287-292.

(5) Schoonman, J.; Wagenaar, K. E. D.; Overshuizen, G. J.; Dirksen, J. J. Electrochem. Soc. 1979, /26, 709-712. solvents. These polymers are soluble in concentrated sulfuric acid, but under these conditions the crown ether moieties are destroyed. Calcium chloride, complexed to the polymers, was removed by repeated sonication with water. Polycondensation of $5 \mathbf{a}-\mathbf{c}$ in quinoline without the catalyst, resulted in high molecular weight polymers as well, but much longer reaction times were required $(\sim 350 \mathrm{~h})$. Under the reaction conditions employed, the 15 crown- 5 derivative 5 a gave higher molecular weight polysiloxanes than the 18-crown-6 5b and the 21-crown-7 5c derivatives (vide infra). The rate of polycondensation apparently depends on the size of the crown ether ring. Compounds $1 \mathrm{a}-\mathrm{c}$ were obtained as dark blue/black powders which were stable up to $280^{\circ} \mathrm{C}$ but which decomposed at higher temperatures.

NMR Spectroscopy. The ${ }^{1} \mathrm{H}$ NMR spectra of the dihydroxysilanes $\mathbf{5 a - c}$ are similar to those of their free base derivatives. ${ }^{6 \mathrm{a}}$ The proton spectrum of $5 \mathrm{c}\left(\mathrm{CD}_{3} \mathrm{OD}, 200 \mathrm{MHz}\right)$ is presented in Figure 2A. Signals for the crown ether protons appear between 3.7 and $4.8 \mathrm{ppm}$, while the aromatic protons afford a broad singlet at $9.4 \mathrm{ppm}$. The $\mathrm{Si}-\mathrm{OH}$ protons are present in the TMS region at $0 \mathrm{ppm}$ (not shown). The pattern of the crown

(6) (a) Sielcken, O. E.; van Tilborg, M. M.; Roks, M. F. M.; Hendriks, R.: Drenth, W.; Nolte, R. J. M. J. Am. Chem. Soc. 1987, 109, 4261-4265 (b) Kobayashi, N.; Lever, A. B. P. Ibid. 1987, 109, 7433-7441. 
ether signals is complex, due to the chemically inequivalent ether fragments.

The ${ }^{13} \mathrm{C}$ NMR $\left(\mathrm{CD}_{3} \mathrm{OD}\right)$ spectrum of $5 \mathrm{c}$ is given in Figure 2B. It shows four different aromatic carbon atoms and the carbon atoms of the crown ether rings. This spectrum is the result of an attached proton test (APT) experiment, which was used together with literature data ${ }^{7 a, 9,10}$ to assign the signals. In this APT experiment, carbon atoms of $\mathrm{CH}$ groups provide negative signals and the signal at $108 \mathrm{ppm}$ can therefore be attributed to carbon atoms $\mathrm{C}_{3}$ and $\mathrm{C}_{3^{\prime}}$. The crown ether signals appear at $72 \mathrm{ppm} .{ }^{9,10}$ The atoms $\mathrm{C}_{1}, \mathrm{C}_{1}$, and $\mathrm{C}_{4}, \mathrm{C}_{4^{\prime}}$ of the $\mathrm{Pc}$ macrocycle have signals at 151 and $155 \mathrm{ppm}$, respectively; ${ }^{7 \mathrm{a}, 10}$ assignment was aided by measurement of a $\mathrm{Pc}$ (with dodecoxy substituents) that had been enriched with ${ }^{13} \mathrm{C}$ at $\mathrm{C}_{1}$ and $\mathrm{C}_{1},{ }^{11}$ The remaining signal at 132 ppm is ascribed to $\mathrm{C}_{2}, \mathrm{C}_{2}$,

The ${ }^{13} \mathrm{C}$ CPMAS spectra of $5 \mathrm{c}$ (not shown) were complicated by spinning side bands and chemical shift data were extracted from several spectra recorded at varying spinning frequencies. As can be seen from Table I, the ${ }^{13} \mathrm{C}$ CPMAS spectra show close analogies to the ${ }^{13} \mathrm{C}$ solution NMR spectra. In the CPMAS spectra, $\mathrm{C}_{1}, \mathrm{C}_{1^{\prime}}$ and $\mathrm{C}_{4}, \mathrm{C}_{4^{\prime}}$ are almost coincident.

The ${ }^{1} \mathrm{H}$ NMR and ${ }^{13} \mathrm{C}$ NMR spectra of oligomeric $5 \mathrm{c}(m=$ $3,4)$ are shown in Figure $2 \mathrm{C}, \mathrm{D}$. The ${ }^{13} \mathrm{C}$ spectrum is analogous to that of the monomer, though all signals, except that of $\mathrm{C}_{3}, \mathrm{C}_{3}$, are split into four and are shifted to higher field. The reason for these phenomena could be that the phthalocyanine macrocycles are arranged in staggered positions $\left(\phi \neq 45^{\circ}\right)$. In these positions the carbon pairs $\mathrm{C}_{1}, \mathrm{C}_{1^{\prime}}, \mathrm{C}_{2}, \mathrm{C}_{2^{\prime}}, \mathrm{C}_{3} \mathrm{C}_{3^{\prime}}$, and $\mathrm{C}_{4}, \mathrm{C}_{4^{\prime}}$ become magnetically inequivalent. ${ }^{7 a}$ The oligomers are thus expected to give a spectral pattern that is more complex than the $D_{4 h}$ MPc monomers. The ${ }^{1} H$ NMR spectrum of monomeric $5 c$ changes dramatically when it is polymerized (Figure $2 \mathrm{~A}, \mathrm{C}$ ). The broad aromatic singlet at $9.4 \mathrm{ppm}$ changes into a very complex pattern of sharp, upfield-shifted signals. The large number of these signals can be explained by the inequivalence of all aromatic protons in the trimer and tetramer. Kenney and co-workers, working with dimeric, trimeric, and tetrameric SiPc compounds, ${ }^{7 b}$ observed a similar increasing upfield shift of the aromatic protons with increasing oligomer length, and they found that signals of the inner protons in the stack are shifted more upfield than those of the outer protons due to the shielding effect of the Pc macrocycles. ${ }^{7 b}$ In our spectra of $\mathbf{5 c}$ we find that the axially coordinated $\mathrm{OH}$ protons in the oligomer are also shifted upfield and that there are two signals present at -3.5 and $-4.0 \mathrm{ppm}$, for the trimer and tetramer, respectively; ${ }^{7 \mathrm{~b}}$ these signals disappear upon adding $\mathrm{CD}_{3} \mathrm{OD}$. A remarkable feature of the spectrum of oligomeric $\mathbf{5 c}$ is the very broad region between 3.4 and $5.2 \mathrm{ppm}$ in which the multiplets of crown ether units occur. Compared to the spectrum of monomeric $5 \mathbf{c}$ the signals are well-separated and spread out, especially in downfield direction. This spectral dispersion could indicate that in the stack the crown ethers have a flattened, more preorganized conformation than in the monomer. The spectrum of the oligomer does not significantly change with increasing

(7) (a) Toscano, P. J.; Marks, T. J. Ibid. 1986, 108, 437-444. (b) Janson, T. R.; Kane, A. R.; Sullivan, J. F.; Knox, K.; Kenney, M. E. Ibid. 1969, 91, $5210-5214$.

(8) (a) Koenig, K. E.; Lein, G. M.; Stückler, P.; Kanada, T.; Cram, D. J. Ibid. 1979, 101, 3553-3566. (b) Nolte, R. J. M.; Cram, D. J. Ibid. 1984, 106, 1416-1420.

(9) (a) Live, D.; Chan, S. I. Ibid. 1976, 98, 3769-3778. (b) Lockhart, J. C.; Robson, A. C. J. Chem. Soc., Dalton Trans. 1978, 611-617. (c) Mosier-Boss, P. A.; Robson, A. I. J. Am. Chem. Soc. 1985, 107, 6168-6174. (d) Buchanan, G. W.; Kirby, R. A.; Charland, J. P. Ibid, 1988, 110, 2477-2483. (e) Lin, J. D.; Popov, A. I. Ibid. 1981, 103, 3773-3777.

(10) Belton, P.S.; Tanner, S. F.; Wright, K. M.; Payne, M. P.; Truter, M. R.; Wingfield, J. N. J. Chem. Soc., Perkin Trans. 2 1985, 1307-1311.

(11) van der Pol, J. F.; Markies, B.; Nolte, R. J. M.; Drenth, W., to be published.

(12) van der Linden, J. H.; Schoonman, J.; Nolte, R. J. M.; Drenth, W. Recl. Trav. Chim. Pays-Bas 1984, 103, 260-263.

(13) (a) Fujimoto, M.; Nogani, T.; Mikawa, H. Chem. Lett. 1982, 8, 547. (b) Newman, D. S.; Hazlett, D.; Mucker, K. F. Solid State Ionics 1981, 314, 389-392.

(14) Nolte, R. J. M.; van Beynen, A. J. M.; Neevel, A. J. M.: Zwikker, J. W.; Verkley, A. J.; Drenth, W. Isr. J. Chem. 1984, 24, 297-301.

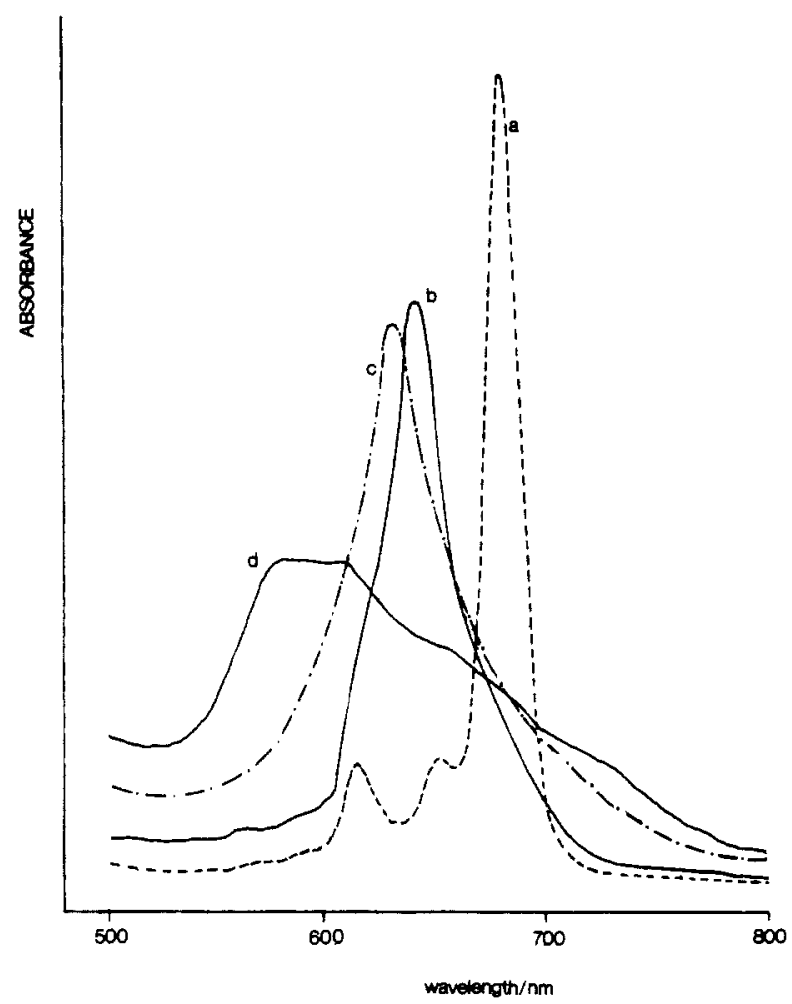

Figure 3. Electronic absorption spectra of monomeric (a), dimeric (b), trimeric (c), and oligomeric (d) products of 5.

temperature and this fact, combined with the observed splitting of the aromatic signals, indicates that the oligomeric compounds have rigid structures. Since addition of KSCN to the oligomeric compounds resulted in a further upfield expansion of the crown ether signals without changes in the aromatic signals, it would appear that complexation of an ion does not influence the staggered conformation of the Pc macrocycles.

The ${ }^{13} \mathrm{C}$ CPMAS NMR spectra of polysiloxanes 1a-c are poorly resolved, and compared to the spectra of $5 c$, the signals are broad. Attempts to separate spinning side bands from the isotropic chemical shifts failed so far. An increase in temperature did not result in any appreciable change of the spectra.

The ${ }^{29} \mathrm{Si}$ CPMAS NMR spectrum of $5 \mathrm{c}$ gave, as expected, one intense singlet at $-110.8 \mathrm{ppm}$ whereas polymers 1 gave two signals, a large multiplet at $-115.1 \mathrm{ppm}$ and a small singlet at $-138.5 \mathrm{ppm}$. The polymer signals come from silicon in two very different environments, namely in $\mathrm{Si}-\mathrm{O}-\mathrm{Si}-\mathrm{O}-\mathrm{Si}$ fragments and in the end groups $\mathrm{Si}-\mathrm{O}-\mathrm{Si}-\mathrm{OH}$. From these spectra (with poor resolution) we were only able to make a rough estimate of the chain lengths of the polymer; the numbers yielded are similar to those obtained by IR spectroscopy (see below).

UV/Vis Spectroscopy. The electronic absorption spectra of monomers 5 and their polycondensation products are given in Figure 3. Monomers 5 show a $Q$ band with maximum at 678 $\mathrm{nm}$ and two weaker bands at 650 and $612 \mathrm{~nm}$. During the condensation process of monomeric 5 to the polycondensation products 1 the degree of conversion can be estimated by following the changes of the bands in the absorption spectra; the monomeric band at $678 \mathrm{~nm}$ loses intensity and simultaneously there appears a new band at $640 \mathrm{~nm}$ that can be ascribed to the dimeric species of 5. ${ }^{3 \mathrm{~h} j, e}$ After $3 \mathrm{~h}$ the band at $678 \mathrm{~nm}$ had almost disappeared. Prolonged reaction times resulted in the appearance of a new band at $634 \mathrm{~nm}$ which we attribute to a trimeric species. For $5 \mathrm{a}$ and 5b further condensation resulted in a precipitate of higher oligomers that is not soluble in organic solvents. Only for $\mathbf{5 c}$ did we obtain a soluble oligomer $(m>3)$, and this gave a broad maximum between 610 and $560 \mathrm{~nm}$. $^{3 \mathrm{n}}$ Apparently, the solubility of these oligomeric compounds increases with increasing size of their crown ether subunits.

The polycondensation process can be followed by TLC as well

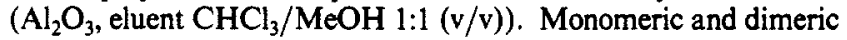




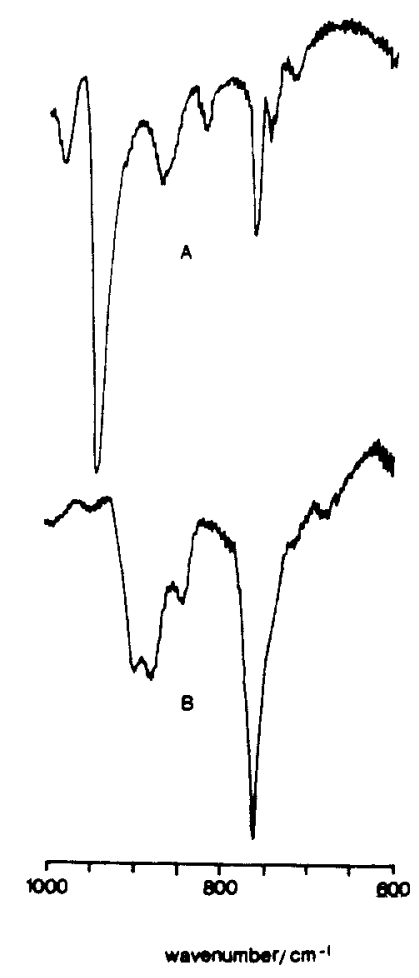

Figure 4. Infrared spectra of 59 (A) and 1a (B).

species can be separated over Sephadex LH 60.

Infrared Spectroscopy. The polycondensation process of 5 to 1 can be readily followed by IR spectroscopy. The spectra of compounds $\mathbf{5}$ differ considerably from those of the unsubstituted silicon phthalocyanines. ${ }^{3 e}$ Unfortunately, most Pc skeleton and $\mathrm{Si}-\mathrm{OH}$ vibrations, which are often used to estimate the chain length by end group analysis, are masked by the vibrations of the crown ether rings. In our condensed compounds the antisymmetric $\mathrm{Si}-\mathrm{O}-\mathrm{Si}$ stretch vibration, which is visible in unsubstituted phthalocyaninato polysiloxanes between 1000 and $1130 \mathrm{~cm}^{-1}$, is dominated by the aliphatic ether bands. This IR method is therefore not expected to give accurate results for the degree of polymerization of our condensed materials.

Figure 4 shows the IR spectra of monomer $5 \mathrm{a}$ and its polymer 1a. The intensity of the absorption band at $870 \mathrm{~cm}^{-1}$, ascribed to the $\mathrm{Si}-\mathrm{OH}$ stretch vibration, ${ }^{3 \mathrm{c}}$ decreases during the polycondensation process and, simultaneously, a complex band between 900 and $840 \mathrm{~cm}^{-1}$ appears. The weak absorption at $820 \mathrm{~cm}^{-1}$, assigned to the antisymmetric $\mathrm{O}-\mathrm{Si}-\mathrm{O}$ stretch vibration, ${ }^{3 e}$ and the bands at 940 and $980 \mathrm{~cm}^{-1}$ disappear as well. Other notable changes upon polymerization are the increase in intensity of the bands at 760 and $1610 \mathrm{~cm}^{-1}$ and the disappearance of the band at $1520 \mathrm{~cm}^{-1}$; the intensity of bands at $1480,1420,1350,1290$, and $1210 \mathrm{~cm}^{-1}$ remain constant. An indication of the chain length of polymers la-c was obtained with use of relative intensities and intensity changes of the IR bands mentioned. The IR spectra of isolated mono-, di-, and trimeric derivatives of 5 were used as references, and for these derivatives the ratio of the absorbances were plotted versus molecular weight. The molecular weights of the polymers were subsequently derived by linear extrapolation. This method can only be applied to polymers with relatively short chain lengths. For samples prepared by heating for $70 \mathrm{~h}$ at 200 ${ }^{\circ} \mathrm{C}$ the degree of polymerization was calculated to be $m=14-18$ for 1a, $m=10-15$ for $1 \mathrm{~b}$, and $m=6-8$ for $1 \mathrm{c}$. These results reveal that the length of the polymers depends on the size of the substituent. The formation of relatively high molecular weight polymers is favored when the substituent is small.

Alkali-Metal Binding. The association constants, $K_{\mathrm{a}}$, and the free energies of complexation, $\Delta G^{\circ}$, of $\mathbf{5 b}$ and $5 \mathbf{c}$ and their corresponding soluble oligomers $(m=3-5)$ with various alkali-metal ions were determined by the picrate extraction method developed by $\mathrm{Cram}^{8}{ }^{8}$ This method is not applicable to $5 \mathrm{a}$ and its oligomers, because not only was 5 a too soluble in water but also there was
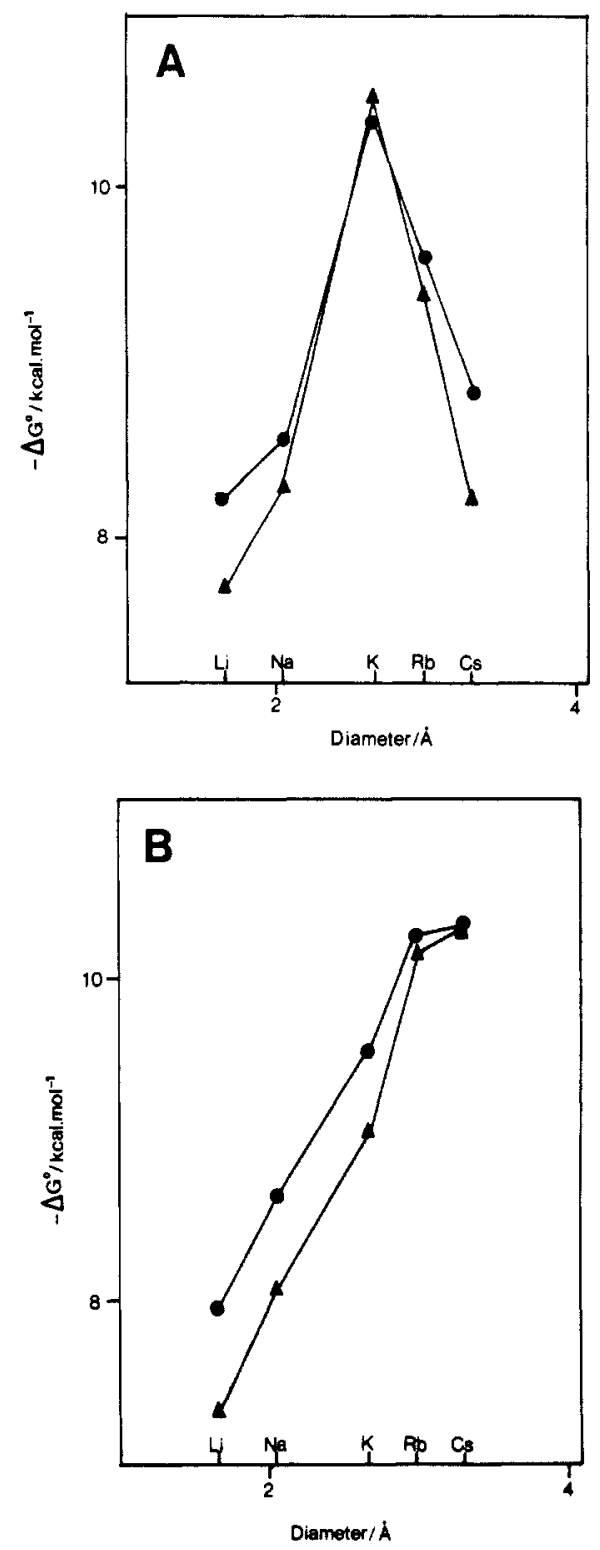

Figure 5. Free energies of binding picrate salt to $5 b(\bullet)$ and of picrate salt to $1 \mathrm{~b}(m=3)(\mathbf{A})(\mathrm{A})$. Free energies of binding of picrate salt to 5c $(\bullet)$ and of picrate salt to oligomer 1c $(m=4-5)(\Delta)(B)$.

strong emulsion formation on addition of picrate. In Table II are presented the association constants $\left(K_{\mathrm{a}}\right)$ which were calculated assuming a $1: 1$ complex formation between crowns and cations. In Figure 5 the $\Delta G^{\circ}$ values of the various complexes (calculated from $K_{\mathrm{a}}$ ) are presented graphically.

For all alkali-metal ions except $\mathrm{Cs}^{+}$, compound $\mathbf{5 b}$ shows a binding profile similar to that of its copper derivative. ${ }^{60}$ Compound 5b is a good complexing agent for $\mathrm{K}^{+}$, because the 18-crown-6 ethers have a diameter that matches the diameter of this ion. The $\mathrm{Rb}^{+}$and $\mathrm{Cs}^{+}$ions are too large to be encapsulated in these crown ethers and they may, therefore, induce dimer formation of the phthalocyanines as was observed for the copper derivative of $\mathbf{5 b}$. $^{\mathbf{6}}$ UV/vis spectra, however, show that such dimer formation does not occur, probably because of steric hindrance by the axial $\mathrm{OH}$ groups. We can not exclude, however, the formation of a noncofacial dimer.

Oligomeric 5c like 5b show a somewhat more selective binding profile toward alkali-metal ions than the monomer. The binding profile of $5 \mathbf{c}$ is similar to that of its copper derivative $e^{6 \mathbf{a}}$ and the 21-crown-7 rings prefer the larger $\mathrm{Rb}^{+}$and $\mathrm{Cs}^{+}$ions over the smaller ions. For oligomeric $\mathbf{5 b}$ and $\mathbf{5 c}$ a further increase in selectivity is to be expected for the higher molecular weight polymers. The reason that the oligomers show more selective binding than the monomers may be related to a difference in 
Table II. Association Constants of Alkali Metal Picrate Salt-Phthalocyanine Complexes

\begin{tabular}{ccc}
\hline host & cation of guest & $K_{\mathrm{a}}, 10^{-5} \mathrm{M}^{-1}$ \\
\hline $\mathbf{5 b}$ & $\mathrm{Li}^{+}$ & 9.8 \\
& $\mathrm{Na}^{+}$ & 16.3 \\
& $\mathrm{~K}^{+}$ & 367 \\
& $\mathrm{Rb}^{3}$ & 104 \\
& $\mathrm{Cs}^{+}$ & 27.2 \\
$\mathbf{1 b}^{2}$ & $\mathrm{Li}^{+}$ & 4.1 \\
& $\mathrm{Na}^{+}$ & 10.8 \\
& $\mathrm{~K}^{+}$ & 481 \\
& $\mathrm{Rb}^{+}$ & 70.8 \\
& $\mathrm{Cs}^{+}$ & 10.4 \\
$5 \mathbf{c c}$ & $\mathrm{Li}^{+}$ & 4.5 \\
& $\mathrm{Na}^{+}$ & 19.7 \\
& $\mathrm{~K}^{+}$ & 88.7 \\
& $\mathrm{Rb}^{+}$ & 292 \\
& $\mathrm{Cs}^{+}$ & 329 \\
& $\mathrm{Li}^{+}$ & 6.3 \\
& $\mathrm{Na}^{+}$ & 7.9 \\
& $\mathrm{~K}^{+}$ & 39.7 \\
& $\mathrm{Rb}^{+}$ & 249 \\
& $\mathrm{Cs}^{+}$ & 315 \\
\hline
\end{tabular}

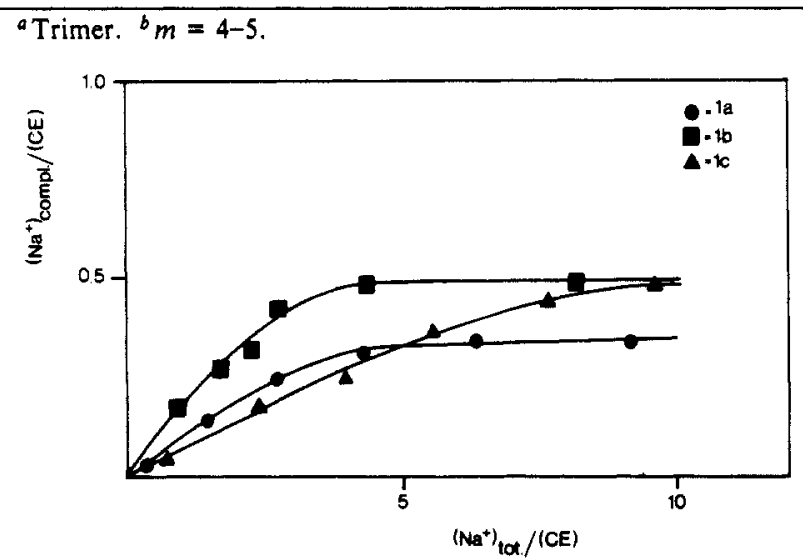

Figure 6. Saturation levels of polymers $1 \mathrm{a}-\mathrm{c}$ for $\mathrm{Na}^{+}$.

conformation of the crown ether rings in the two systems. An isolated crown ether has a folded conformation, ${ }^{15}$ and this conformation becomes more planar upon binding a cation. Because of the packed structure of the oligomers, the crown ethers are already forced into a more planar conformation. Upon complexing an ion with a small diameter, the most favorable conformation for binding cannot be attained. This results in a lower $\Delta G^{\circ}$ value for the oligomers than for the free crown ether. Another aspect that may play a role in complexing ions in the oligomers is electrostatic repulsion. Preorganization of the crown ethers in the oligomers will facilitate complexation of $\mathrm{K}^{+}$to $\mathbf{1 b}$ and of $\mathrm{Rb}^{+}$ and $\mathrm{Cs}^{+}$to $1 \mathrm{c}$. However, because of the packed structure of the oligomers, electrostatic repulsion between the complexed ions may prevent complete saturation of the crown ethers.

Information on the saturation level of cations in the phthalocyaninato polysiloxanes 1a-c was derived from extraction experiments on the solid polymers using varying amounts of aqueous sodium picrate solutions. The results obtained were corrected for adsorption of the picrate salts to solid samples. To this end similar experiments were performed with solid $\mathrm{H}_{2} \mathrm{Pc}$. The results are presented in Figure 6. For both the 18-crown-6 and 21-crown-7 polymers, 1 b and $1 c$, a saturation level of complexed $\mathrm{Na}^{+}$ $\left(\mathrm{Na}^{+}{ }_{\text {compl }}\right)$ to crown ether $(\mathrm{CE})$ ratio of 0.48 was obtained. The saturation level of $\mathbf{1} \mathbf{c}$ is reached at a higher overall cation to crown ether ratio than that of $\mathbf{1 b}$, because $\mathrm{Na}^{+}$is less effectively bound in the 21-crown-7 rings. For the 15-crown-5 polymer, 1a, a saturation level of 0.34 was measured. The maximum $\left(\mathrm{Na}^{+}{ }_{\text {compl }}\right) /(\mathrm{CE})$ ratio of 1.0 is not reached in our polymers because of the above-mentioned electrostatic repulsion between the com-

(15) Izatt, R. M.; Christensen, J. J., Eds. Progress in Macrocyclic Chemistry, Wiley: New York, 1981
Table III. Electronic Conductivities ( $\sigma$ ) and Conduction Activation Energies $\left(E_{\mathrm{a}}\right)$

\begin{tabular}{cll}
\hline compound & \multicolumn{1}{c}{$\sigma, \mathrm{S} \mathrm{m}^{-1}$} & $E_{\mathrm{a}}, \mathrm{eV}$ \\
\hline $\mathbf{5 a - c}$ & $<10^{-9}$ & - \\
$\mathbf{1 a}$ & $7 \times 10^{-7}\left(25^{\circ} \mathrm{C}\right)$ & 0.23 \\
$\mathbf{1 b}$ & $3 \times 10^{-7}\left(25^{\circ} \mathrm{C}\right)$ & 0.29 \\
$\mathbf{1 c}$ & $1 \times 10^{-8}\left(100^{\circ} \mathrm{C}\right)$ & 0.38 \\
\hline
\end{tabular}

plexed cations. This is supported by results from similar measurements on rigid poly(isocyanides) with pendant crown ether moieties. ${ }^{16}$ For these polymers also a cation to crown ether ratio lower than 1 was found even for ions with diameters that match the size of the crown ethers.

Electronic Conductivity. The electrical properties of phthalocyanines 5 and 1 were studied in the solid state by ac impedance spectroscopy..$^{\text {lbe }}$ All spectra revealed one semicircular arc, indicating that the materials behave as a dielectric with a minor contribution of electronic conductivity. Seebeck measurements showed that compounds 1a-c are p-type electronic conductors. The impedance spectra of $1 \mathrm{a}-\mathrm{c}$ could be fitted to the equivalent circuit $R_{\mathrm{b}} Q_{\mathrm{p}}$, where p stands for parallel, $R_{\mathrm{b}}$ represents the bulk electronic resistance, and $Q$ is the constant phase element (CPE), with an impedance $Z=\left(k(i \omega)^{\alpha}\right)^{-1}$. For all samples the CPE has a value for $\alpha$ of about 0.9 , and has, therefore, the character of a capacitance. Compounds $5 \mathrm{a}-\mathrm{c}$ and their dimeric and trimeric derivatives could not be measured accurately by ac impedance spectroscopy, because these compounds had bulk resistances that were too high.

The electronic conductivity, $\sigma$, and the conductivity activation energy, $E_{\text {a }}$, calculated from the $\ln \sigma$ vs $1 / T$ plots are presented in Table III. As can be seen from this table, the electronic conductivity increases upon polymerization of the monomeric compounds 5 . The higher molecular weight polymers $1 \mathrm{a}$ and $\mathbf{1 b}$ show larger values for $\sigma$ than the lower molecular weight polymer 1c. The explanation for this is that charge transport will be facilitaed in longer chains of Pc units because the number of intermolecular barriers that the charge carriers have to cross, is reduced. The conduction activation energies of $1 a-c$ differ only slightly in magnitude. The $E_{\mathrm{a}}$ values may be dependent on the intrinsic charge formation activation energy, $\Delta E_{f}$, on the activation energy of intramolecular charge migration, $\Delta E_{\mathrm{m}}^{\text {intra }}$, and on the activation energy of intermolecular charge crossing, $\Delta E_{\mathrm{m}}^{\text {inter }}$. In our case we are inclined to believe that the $E_{\mathrm{a}}$ values are to be correlated with migration only. Previously, we showed that the sum of $\Delta E_{\mathrm{f}}$ and $\Delta E_{\mathrm{m}}^{\text {inter }}$ has values over $1 \mathrm{eV} .^{\text {lc }} \Delta E_{\mathrm{m}}^{\text {inter }}$ is dependent on the distance between the stacks, which in turn is determined by the size of the crown ether rings. Indeed, Table III shows that the $E_{\mathrm{a}}$ value decreases in the series $1 \mathrm{c}>1 \mathbf{b}>\mathbf{1 a}$.

Ionic Conductivity. The occurrence of ionic conduction in compounds $1 \mathrm{a}-\mathrm{c}$ was tested by using these polymers as a membrane in the concentration cell Na-amalgam(I)/Na picrate (30 $\mathrm{mol} \%$ )-polymer complex|Hg(II). The open-circuit voltage (OCV) of this cell was measured at various time intervals of utilization in the discharge mode at $80^{\circ} \mathrm{C}$. For the 15 -crown-5 polysiloxane $1 \mathrm{a}$ and the 18-crown-6 polysiloxane $1 \mathrm{~b}$, no decrease of the $\mathrm{OCV}$ was observed during a period of $72 \mathrm{~h}$. This result indicates that compounds $1 \mathrm{a}$ and $1 \mathrm{~b}$ are not able to transport sodium ions, the rationale being the strong complexation of sodium ions by these polymers. For the 21 -crown-7 polymer $1 \mathrm{c}$, the OCV decreased with time from a starting value of approximately $1.5 \mathrm{~V}$. This initial value is not well defined because $a_{\mathrm{Na}}$ (II) $=0$ at $t=0$. After 24 $\mathrm{h}$, the OCV was $1.28 \mathrm{~V}$ and in the following period of $95 \mathrm{~h}$, the OCV decreased to $0.73 \mathrm{~V}$. Subsequent replacement of the $\mathrm{Na}$ amalgam(I) electrode for $\mathrm{Hg}$ resulted in an OCV of $-0.22 \mathrm{~V}$. These data reveal that the 21 -crown-7 polymer $1 \mathrm{c}$ does conduct sodium ions. From the open-circuit-voltage (OCV), load-circuit-voltages (LCV), and load-current $\left(I_{\mathrm{L}}\right)$ data for the concentration cell in the discharge mode, a discharge curve LCV/OCV vs $I_{\mathrm{L}}$ was constructed (Figure 7). From the linear part of this 


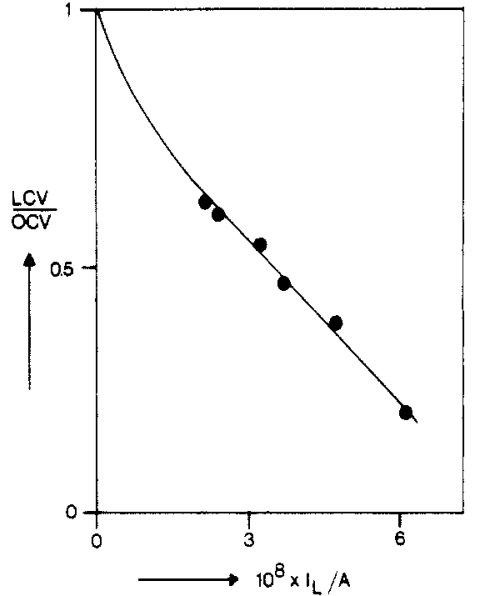

Figure 7. Normalized load-circuit voltages vs load currents for a concentration cell with a sodium picrate-1e complex as membrane; $T=80$ ${ }^{\circ} \mathrm{C}$.

plot, an $R_{\mathrm{dc}}$ of $1.3 \times 10^{7} \Omega$ was calculated. This $R_{\mathrm{dc}}$ value is very high compared to that found for $\mathrm{K}^{+}$transport through a polymer of poly (isocyanide) containing 18-crown-6 rings. ${ }^{12}$ An appreciable cation transport is only expected for ions having low free energies of complexation, i.e., for ions having an ionic diameter small compared to that of the crown ether, ${ }^{14}$ and this is the case of sodium complexed in the 21-crown-7 polymer 1c. However, the $R_{\mathrm{dc}}$ value indicates that transport of sodium is very low. This feature can be explained by the structural difference of the two polymers. In the poly(isocyanide) the crown ether rings are stacked on top of each other and form extended channels whereas in 1c the Pc units have a staggered arrangement. This latter arrangement could result in distortion or even the complete absence of a channel structure, and therefore, ion transport may be hindered or even prevented. Better results for cationic conductivity are to be expected for $\mathrm{Pc}$ polymers containing crown ether rings larger than 21-crown-7. The present data reveal that the crown ether rings and their size do play a distinctive role in cationic conductivity.

\section{Experimental Section}

Infrared spectra were measured on Perkin-Elmer 283 and PerkinElmer 1800 instruments. UV/vis spectra were recorded on a PerkinElmer 555 spectrometer. Solution ${ }^{1} \mathrm{H}$ NMR and ${ }^{13} \mathrm{C}$ NMR spectra were recorded on Varian EM 360, Bruker WP 200, and Bruker AM 400 instruments. Tetramethylsilane was used as the internal standard. ${ }^{29} \mathrm{Si}$, ${ }^{1} \mathrm{H}$, and ${ }^{13} \mathrm{C}$ CPMAS-NMR spectra were recorded on Bruker AM 500 and Bruker CXP 300 spectrometers. Abbreviations used are as follows: $\mathrm{s}=$ singlet, $\mathrm{d}=$ doublet, $\mathrm{t}=$ triplet, $\mathrm{q}=$ quartet, $\mathrm{b}=$ broad, and $\mathrm{sh}=$ shoulder. FAB mass spectra were recorded on a VG ZAB $2 F$ spectrometer. Elemental analyses were performed by the Elemental Analytical Section of the Institute for Applied Chemistry TNO, Zeist, The Netherlands.

Seebeck measurements were performed as described previously. ${ }^{1 b}$ Impedance spectra were recorded in the temperature range of $25-250^{\circ} \mathrm{C}$ and analyzed as described earlier. ${ }^{16}$

Ionic conductivity experiments were performed using concentration cells of the type $\mathrm{Na}$-amalgam(I)|Na picrate $(30 \mathrm{~mol} \%)-1 \mid \mathrm{Hg}$ (II). In the discharge mode, the de resistance $\left(R_{\mathrm{dc}}\right)$ was determined from normalized load-circuit voltages (LCV/OCV) vs load-current densities $\left(I_{\mathrm{L}}\right)$, the relation between these parameters being ${ }^{5}$

$$
\frac{\mathrm{LCV}}{\mathrm{OCV}}=-\frac{R_{\mathrm{dc}}}{\mathrm{OCV}} I_{\mathrm{L}}+1
$$

where OCV represents the open-circuit voltage of the concentration cell. The OCV is governed by the Nernst expression

$$
\mathrm{OCV}=\frac{k T}{q} \ln \frac{a_{\mathrm{Na}}(\mathrm{I})}{a_{\mathrm{Na}}(\mathrm{II})}
$$

OCV and LCV were recorded with a Teletec Airtronic TE 924 electrometer. The sodium amalgam was prepared by dissolving $57 \mathrm{mg}$ of sodium in $101 \mathrm{~g}$ of $\mathrm{Hg}$ under an atmosphere of dry nitrogen. The mixture was subsequently heated at $300^{\circ} \mathrm{C}$ for $1 \mathrm{~h}$. The polymer $1-\mathrm{Na}$ picrate complex was prepared as under the Saturation Experiments section. The sample was washed with water and dried under vacuum

4,5-Dicyanobenzo-15-crown-5 (2a), 4,5-dicyanobenzo-18-crown-6 (2b), and 4,5-dicyanobenzo-21-crown-7 (2c) were prepared as described previously ${ }^{6 a}$

1,3-Diimino-5,6-(1,4,7,10,13-pentaoxatridecamethylene)-1,3-dihydroisoindole (3a). Anhydrous ammonia was bubbled through a solution of $1.75 \mathrm{~g}(5.5 \mathrm{mmol})$ of $2 \mathrm{a}$ and $0.51 \mathrm{~g}(9.4 \mathrm{mmol})$ of sodium methoxide in $50 \mathrm{~mL}$ of absolute methanol at room temperature for 30 min during which time the color of the solution turned from colorless to green. The solution was heated for $4 \mathrm{~h}$ at $95^{\circ} \mathrm{C}$ while the addition of ammonia was continued and then cooled to room temperature. A white precipitate of sodium methoxide was filtered off, and the filtrate was evaporated to dryness. The remaining solid was extracted with dry chloroform. Remaining sodium salts, complexed in the crown ethers, were removed with an ion-exchange resin (Amberlyst 15). After recrystallization in dry chloroform, $1.3 \mathrm{~g}$ of a light green solid was obtained: yield $83 \% ; \mathrm{mp} 108$ ${ }^{\circ} \mathrm{C}$ dec; FAB MS $m / e 336(\mathrm{M}+\mathrm{H})^{+}$; IR (KBr) $3400(\mathrm{NH}), 3200$ (NH), 2910-2870 $\left(\mathrm{CH}_{2}\right), 1630(\mathrm{C}-\mathrm{N}), 1110-1040(\mathrm{COC}) \mathrm{cm}^{-1} ;{ }^{1} \mathrm{H}$ NMR (DMSO-d $\left.d_{6}\right) \delta 3.6-4.4\left(\mathrm{~m}, 16 \mathrm{H}, \mathrm{CH}_{2} \mathrm{O}\right), 7.3(\mathrm{~s}, 2 \mathrm{H}, \mathrm{ArH})$, 7.7-8.2 (br s, $3 \mathrm{H}, \mathrm{NH}) \mathrm{ppm}$.

Dihydroxy $\left[4,5: 4^{\prime}, 5^{\prime}: 4^{\prime \prime}, 5^{\prime \prime}: 4^{\prime \prime \prime}, 5^{\prime \prime \prime}\right.$-tetrakis $(1,4,7,10,13$-pentaoxatridecamethylene)phthalocyaninatosilicon(IV) $(5 \mathrm{a})$. To a mixture of $1.33 \mathrm{~g}$ $(3.99 \mathrm{mmol}$ ) of $3 \mathrm{a}$ in $10 \mathrm{~mL}$ of quinoline (freshly distilled from barium oxide) was added, under an atmosphere of $\mathrm{N}_{2}, 2 \mathrm{~mL}(17 \mathrm{mmol})$ of $\mathrm{SiCl}_{4}$. The temperature of the mixture was quickly brought to $100^{\circ} \mathrm{C}$ and kept there for $12 \mathrm{~h}$. At the end of this time the reaction mixture was brown. After cooling, an excess of $\mathrm{SiCl}_{4}$ was distilled off, $20 \mathrm{~mL}$ of water was added, and the mixture was stirred for $4 \mathrm{~h}$. In this period the color changed from brown to green. A precipitate was filtered off, and the clear filtrate was added dropwise to ethyl acetate. The green precipitate of the product which formed was filtered off and washed with acetone. Recrystallization of $5 \mathrm{a}$ was performed by slowly evaporating ether into a solution of the product in pyridine. The solid was filtered off, dried, and further purified by gel permeation chromatography (Sephadex LH 60 , eluent $\mathrm{CHCl}_{3} / \mathrm{MeOH} 1: 1$ ). An amount of $395 \mathrm{mg}$ of a dark green solid was obtained: yield $30 \%$; TGA $310^{\circ} \mathrm{C}$, FAB MS m/e $1335(\mathrm{M}$ $+\mathrm{H})^{+}$; IR (KBr) $3400(\mathrm{OH}), 2910-2885\left(\mathrm{CH}_{2}\right), 1100-1060(\mathrm{COC})$ $\mathrm{cm}^{-1} ;{ }^{1} \mathrm{H} \mathrm{NMR}\left(\mathrm{CDCl}_{3}, 60 \mathrm{MHz}\right) \delta 0.0(\mathrm{~s}, 2 \mathrm{H}, \mathrm{SiOH}), 3.3-4.5(\mathrm{~m}, 64$ $\left.\mathrm{H}, \mathrm{CH}_{2} \mathrm{O}\right), 8.0-8.5($ br s, $8 \mathrm{H}, \mathrm{ArH}) ; \mathrm{UV} /$ vis $\left(\mathrm{CHCl}_{3}\right) \lambda_{\max }(\log \epsilon) 678$ (5.3), $650(4.6), 612(4.6), 444(\mathrm{sh}), 417(4.6), 359(5.0) \mathrm{nm}$. Anal. Calcd for $\mathrm{C}_{64} \mathrm{H}_{24} \mathrm{SiN}_{8} \mathrm{O}_{22}$ : C, $57.56 ; \mathrm{H}, 5.59 ; \mathrm{N}, 8.39$. Found: C, 58.8; $\mathrm{H}, 5.6 ; \mathrm{N}, 8.3$ (different samples gave varying results with a maximum variation of about $1.5 \%$ for all elements). (4a: UV/vis (pyridine) $\lambda_{\max }$ 702, 680-664 (sh), 630 (sh), 612-604 (sh), 444, 417 (sh), $372 \mathrm{~nm}$.)

Polycondensation of 5a To Give 1a. A mixture of $0.25 \mathrm{~g}(0.19 \mathrm{mmol})$ of $5 \mathrm{a}$ in $20 \mathrm{~mL}$ of quinoline (freshly distilled) from barium oxide and a catalytic amount of $\mathrm{CaCl}_{2}$ was heated under an atmosphere of $\mathrm{N}_{2}$ at 200 ${ }^{\circ} \mathrm{C}$ for $70 \mathrm{~h}$. The resulting dark blue/black powder was isolated by filtration and washed by using a sonicator at $50^{\circ} \mathrm{C}$ with subsequently $\mathrm{H}_{2} \mathrm{O}(3 \mathrm{x})$, DMSO, pyridine, and $\mathrm{CHCl}_{3}$. The product was dried over $\mathrm{P}_{2} \mathrm{O}_{5}$ under reduced pressure: yield $0.2 \mathrm{~g}(80 \%) ;$ TGA $280^{\circ} \mathrm{C}$ dec. Anal. Calcd for $\left(\mathrm{C}_{64} \mathrm{H}_{72} \mathrm{~N}_{8} \mathrm{O}_{21} \mathrm{Si}\right)_{n}$ : C, 58.3; H, 5.5; N, 8.5. Found: C, 59.6; $\mathrm{H}, 4.3 ; \mathrm{N} 9.1$ (different samples gave varying results with a maximum variation of about $1.5 \%$ for all elements). For other physical properties, see text.

1,3-Diimino-5,6-(1,4,7,10,13,16-hexaoxahexadecamethylene)-1,3-dihydroisoindole (3b). This compound was synthesized from $2 \mathrm{~b}$ as described for 3a: yield $74 \%$; $\mathrm{mp} 95^{\circ} \mathrm{C}$ dec; FAB MS m/e $380(\mathrm{M}+\mathrm{H})^{+}$; IR $(\mathrm{KBr})$ as for $3 \mathrm{a} ;{ }^{1} \mathrm{H}$ NMR $\left(\mathrm{CDCl}_{3}\right) \delta 3.6-4.4\left(\mathrm{~m}, 20 \mathrm{H}, \mathrm{CH}_{2} \mathrm{O}\right), 5.4$ (s, $1 \mathrm{H}, \mathrm{NH}), 7.4$ (s, $2 \mathrm{H}, \mathrm{ArH}), 7.6$ (br s, $2 \mathrm{H}, \mathrm{NH}) \mathrm{ppm}$.

Dihydroxy $4,5: 4^{\prime}, 5^{\prime}: 4^{\prime \prime}, 5^{\prime \prime}: 4^{\prime \prime \prime}, 5^{\prime \prime \prime}$-tetrakis $(1,4,7,10,13,16$-hexaoxahexadecamethylene)phthalocyaninatojsilicon(IV) (5b). This compound was synthesized from $3 \mathrm{~b}$ as described for $5 \mathrm{a}$ : yield $25 \%$; TGA $310^{\circ} \mathrm{C}$ dec; FAB MS $m / e 1511(\mathrm{M}+\mathrm{H})^{+}$; UV/vis $\left(\mathrm{CHCl}_{3}\right)$ and $\mathrm{IR}(\mathrm{KBr})$ as for 5a; ' $\mathrm{H} \mathrm{NMR}\left(\mathrm{CDCl}_{3}, 200 \mathrm{MHz}\right) \delta 3.3-4.5\left(\mathrm{~m}, 80 \mathrm{H}, \mathrm{CH}_{2} \mathrm{O}\right), 9.4$ (br $\mathrm{s}, 8 \mathrm{H}, \mathrm{ArH}) \mathrm{ppm}$. Anal. Caled for $\mathrm{C}_{72} \mathrm{H}_{90} \mathrm{~N}_{8} \mathrm{O}_{26} \mathrm{Si}$ : C, 57.21; $\mathrm{H}, 6.00$ $\mathrm{N}, 7.41$. Found: $\mathrm{C}, 56.2 ; \mathrm{H}, 5.9 ; \mathrm{N}, 7.5$ (different samples gave varying results with a maximum variation of about $1.5 \%$ for all elements).

Polycondensation of $5 \mathrm{~b}$ To Give $1 \mathrm{~b}$. Compound $1 \mathrm{~b}$ was synthesized from $5 \mathrm{~b}$ as described for $1 \mathrm{a}$ : yield $69 \%$; TGA $280^{\circ} \mathrm{C}$ dec. Anal. Calcd for $\left(\mathrm{C}_{72} \mathrm{H}_{88} \mathrm{~N}_{8} \mathrm{O}_{25} \mathrm{Si}\right)_{n}$ : C, $57.89 ; \mathrm{H}, 5.95 ; \mathrm{N}, 7.50$. Found: $\mathrm{C}, 58.4 ; \mathrm{H}$, $5.7 ; \mathrm{N}, 8.1$.

1,3-Diimino-5,6-(heptaoxanonadecamethylene)-1,3-dihydroisoindole (3c). This compound was synthesized from $2 c$ as described for $3 a$ : yield $56 \%$; mp $102^{\circ} \mathrm{C} \mathrm{dec}$; FAB MS, $m / e 424(\mathrm{M}+\mathrm{H})^{+}$; IR (KBr) as for 3a; ' ${ }^{\mathrm{H}} \mathrm{NMR}\left(\mathrm{CDCl}_{3}\right) \delta 3.6-4.4\left(\mathrm{~m}, 24 \mathrm{H}, \mathrm{CH}_{2} \mathrm{O}\right), 7.3(\mathrm{~s}, 2 \mathrm{H}, \mathrm{ArH})$, 7.4-7.8 (br s, $3 \mathrm{H}, \mathrm{NH}) \mathrm{ppm}$

Dihydroxy $\left(4,5: 4^{\prime}, 5^{\prime}: 4^{\prime \prime}, 5^{\prime \prime}: 4^{\prime \prime \prime}, 5^{\prime \prime \prime}\right.$-tetrakis $(1,4,7,10,13,16,19$-heptaoxanonadecamethylene)phthalocyaninato)silicon(IV) (5c). This compound 
was synthesized from $3 \mathrm{c}$, as described for $5 \mathrm{a}$ : yield $32 \%$; TGA $350^{\circ} \mathrm{C}$ $\mathrm{dec}$; UV/vis and IR (KBr) as for $5 \mathrm{a}$; ' $\mathrm{H}$ NMR $\left(\mathrm{CD}_{3} \mathrm{OD}\right) \delta 3.7-4.5(\mathrm{~m}$, $96 \mathrm{H}, \mathrm{CH}_{2} \mathrm{O}$ ), 9.4 (br s, $8 \mathrm{H}, \mathrm{ArH}$ ) ppm. Anal. Calcd for $\mathrm{C}_{80} \mathrm{H}_{106} \mathrm{~N}_{8} \mathrm{O}_{30} \mathrm{Si}$ : C, $58.69 ; \mathrm{H}, 6.07 ; \mathrm{N}, 6.37$. Found: $\mathrm{C}, 57.9 ; \mathrm{H}, 6.2$; $\mathrm{N}, 6.5$ (different samples gave varying results with a maximum variation of about $1.5 \%$ for all elements).

Polycondensation of 5c To Give 1c. This compound was synthesized from $5 \mathrm{c}$ as described for $1 \mathrm{a}$ : yield $71 \%$, TGA $285^{\circ} \mathrm{C}$ dec. Anal. Calcd for $\left(\mathrm{C}_{86} \mathrm{H}_{104} \mathrm{~N}_{8} \mathrm{O}_{29} \mathrm{Si}\right)_{n}: \mathrm{C}, 59.30 ; \mathrm{H}, 6.02 ; \mathrm{N}, 6.43$. Found: $\mathrm{C}, 60.4 ; \mathrm{H}$, $6.2 ; \mathrm{N}, 6.3$ (different samples gave varying results with a maximum variation of about $1.5 \%$ for all elements).

Dimeric, Trimeric, and Oligomeric Products of 5a-c. Soluble dimeric and trimeric compounds of $5 \mathrm{a}-\mathrm{c}$ were obtained by heating the monomers in freshly distilled quinoline at $200^{\circ} \mathrm{C}$ with a catalytic amount of $\mathrm{CaCl}_{2}$, under an atmosphere of $\mathrm{N}_{2}$, for 2 and $5 \mathrm{~h}$, respectively. The reaction mixture was filtered, and the solid product was obtained as a black precipitate by slowly evaporating ether into the reaction mixture. The solid was filtered off, dissolved in chloroform, and washed with water. The products were separated by gel permeation chromatography (Sephadex $\mathrm{LH}$ 60, eluent $\mathrm{CHCl}_{3} / \mathrm{MeOH}$ 1:1). Their molecular weights were estimated by ${ }^{1} \mathrm{H}$ NMR by using the integral ratio $\mathrm{ArH} / \mathrm{SiOH}$. Soluble oligomeric $5 \mathbf{c}$ was prepared in a similar way but with a reaction time of $30 \mathrm{~h}$.

Determination of $K_{\text {and }} \Delta G^{\circ}$ Values. The $K$ values were determined by the picrate extraction technique from $\mathrm{H}_{2} \mathrm{O}$ into $\mathrm{CHCl}_{3}$ at $25^{\circ} \mathrm{C}$ as described in the literature. ${ }^{8}$ The $\Delta G^{\circ}$ values were calculated from the $K_{\mathrm{a}}$ values by using the expression $\Delta G^{\circ}=-\mathrm{R} T \ln K_{\mathrm{a}}$
Saturation Experiments. The complex stoichiometries of $\mathrm{Na}^{+}$in compounds 1a-c were determined by shaking the powdered solid polymers $(\sim 4 \mathrm{mg})$ with picrate solutions $\left(10^{-3} \mathrm{M}\right)$ for $7 \mathrm{~h}$ at $25^{\circ} \mathrm{C}$ with a Griffin flask shaker. From the decrease of picrate concentrations, measured spectrophotometrically, the complexed cation to crown ether ratio was determined by plotting the molar ratio of the complexed sodium ions $\left(\mathrm{Na}^{+}{ }^{+}\right)$to host (CE) vs the molar ratio of the total amount of sodium present $\left(\mathrm{Na}^{+}{ }_{\text {tot }}\right.$ ) and host (CE). Solid $\mathrm{H}_{2} \mathrm{Pc}$ was used as a reference compound to measure the adsorption of picrate salts to solid material.

Acknowledgment. We thank Prof. J. H. van der Maas for recording and discussing the infrared spectra, Mr. C. Versluis for recording the FAB Mass spectra, Mrs. G. Nagtegaal, and Mr. A. Kentgens for helping recording and discussing the CPMAS spectra, and Mr. A. Swolfs for running the $400-\mathrm{MHz}$ NMR spectra. Part of this work was supported by the Netherlands Foundation for Chemical Research (SON) with financial aid from the Netherlands Foundation for Scientific Research (NWO).

Registry No. 1a (homopolymer), 118443-49-5; 1b (homopolymer), 125541-37-9; 1c (homopolymer), 125541-39-1; 2a, 110682-73-0; 2b, 108695-56-3; 2c, 108695-57-4; 3a, 116285-46-2; 3b, 125541-32-4; 3c, 125541-33-5; 5a, $118342-88-4 ;$ 5b, 125541-41-5; 5c, 125541-42-6; $\mathrm{SiCl}_{4}$, 10026-04-7; $\mathrm{Li}^{+}, 7439-93-2 ; \mathrm{Na}^{+}, 7440-23-5 ; \mathrm{K}^{+}, 7440-09-7 ; \mathrm{Rb}^{+}$, 7440-17-7; $\mathrm{Cs}^{+}, 7440-46-2$; ammonia, 7664-41-7.

\title{
An Annulation Method for the Synthesis of Highly Substituted Polycyclic Aromatic and Heteroaromatic Compounds
}

\author{
Rick L. Danheiser, ${ }^{*}$ Ronald G. Brisbois, James J. Kowalczyk, and Raymond F. Miller \\ Contribution from the Department of Chemistry, Massachusetts Institute of Technology, \\ Cambridge, Massachusetts 02139. Received September 27, 1989
}

\begin{abstract}
A general strategy for the synthesis of highly substituted polycyclic aromatic and heteroaromatic compounds has been developed. The new aromatic annulation is achieved simply by the irradiation of a dichloroethane solution of an acetylene derivative and a vinyl or aryl $\alpha$-diazo ketone. Mechanistically, the reaction proceeds via the photochemical Wolff rearrangement of the diazo ketone to generate an aryl- or vinylketene, followed by a cascade of three pericyclic reactions. A variety of substituted phenols, naphthalenes, benzofurans, benzothiophenes, indoles, and carbazoles can be prepared by using the method. The application of the aromatic annulation to the total synthesis of the marine alkaloid hyellazole demonstrates the synthetic utility of the method.
\end{abstract}

The invention of efficient methods for the synthesis of substituted aromatic compounds has commanded the interest of chemists since the time of the earliest synthetic organic investigations in the 19th century. Classical approaches to aromatic compounds exploited readily available benzene derivatives and relied heavily on electrophilic and nucleophilic substitution reactions. In recent years, directed metalation reactions have joined the classical substitution methods as another vehicle for the introduction of substituents onto preexisting aromatic rings.

A second approach to highly substituted aromatic compounds involves the application of annulation methods: convergent strategies in which the aromatic system is assembled from acyclic precursors in a single step, with all (or most) substituents already in place. Annulation strategies enjoy several advantages over classical linear substitution strategies, especially when applied to the preparation of highly substituted target molecules. For example, annulation routes frequently avoid the regiochemical ambiguities associated with aromatic substitution reactions and provide access to substitution patterns that cannot be obtained via the more conventional routes. The intrinsic convergent nature of annulation strategies facilitates the efficient assembly of highly substituted aromatics that would require long, multistep routes using classical substitution methodology.
Particularly noteworthy aromatic annulations ${ }^{l}$ which have been developed recently include methods based on Diels-Alder chemistry, ${ }^{2}$ carbonyl condensation reactions, ${ }^{3}$ and transition-metalmediated processes. Prominent among the last class of reactions are the cobalt-mediated $[2+2+2]$ acetylene cycloadditions investigated by Vollhardt ${ }^{4}$ and the Dötz reaction of Fischer carbene complexes. ${ }^{5}$ We have recently shown that addition of vinylketenes

(1) For reviews, see: (a) Bamfield, P.; Gordon, P. F. Chem. Soc. Rev. 1984, 13, 441. (b) Wedenmeyer, K. F. In Methoden der organischen Chemie (Houben-Weyl); Muller, E., Ed.; George Theime: Stuttgart, 1976; Vol. 6/1c, pp 853-924.

(2) Recent examples: (a) Snowden, R. L.; Wüst, M. Tetrahedron Lett. 1986, 27, 703. (b) Boger, D. L.; Mullican, M. D. Organic Syntheses 1987 65, 98. (c) Ziegler, T.; Layh, M.; Effenberger, F. Chem. Ber. 1987, 120, 1347 and references cited therein.

(3) Recent examples: (a) Tius, M. A.; Gomez-Galeno, J. Tetrahedron Lett. 1986, 27, 2571. (b) Chan, T. H.; Prasad, C. V. C. J. Org. Chem. 1986, 51,3012 .

(4) Vollhardt, K. P. C. Angew. Chem., Int. Ed. Engl. 1984, 23, 539

(5) (a) Dötz, K. H.; Fischer, H.; Hofmann, P.; Kriessel, F. R.; Schubert, U.; Weiss, K. Transition Metal Carbene Complexes; Verlag Chemie International: Deerfield Beach, FL, 1984. (b) Dötz, K. H. Angew. Chem., Int. Ed. Engl. 1984, 23, 587. (c) Wulff, W. D. In Advances in Metal-Organic Chemistry; Liebeskind, L. S., Ed.; JAI Press Inc.: Greenwich, CT, 1989; Vol. 